\title{
The Importance of Financial Literacy: Household's Income Mobility Measurement and Decomposition Approach
}

\author{
Melcah Pascua MONSURA ${ }^{1}$
}

Received: September 10, 2020 Revised: November 08, 2020 Accepted: November 16, 2020

\begin{abstract}
This study introduced income mobility analysis using pseudo-longitudinal panel data from Family Income and Expenditure Survey (FIES) to consider the dynamic process of individual's well-being through time. Since there is no comprehensive measurement of income mobility because of its dynamic process, various income mobility indices such as Chi-square, Average Jump Index, Atkinson et al. Mobility Ratio, and Shorrocks' Mobility Index were used. These indices revealed that Filipino households' income movements are more mobile than expected, and their income status improved from 2000 to 2015 . As income mobility takes place, income inequality is reduced by 91.80 percent ( $91.80 \%$ ). Furthermore, the growth effect is the main factor of income mobility. This indicates that households took the economic opportunities from economic growth to earn more. However, income mobility due to transfer effect (transfer of income from one household to another through lottery winning and borrowing) increased when the economy is not good. The higher income mobility due to growth effect compared to transfer effect, whether the economy is good or bad, means that households learned how to use their income in savings, investments, and entrepreneurship. This is the result of a successful financial literacy program of the government wherein households realized financial stability and security.
\end{abstract}

Keywords: Economic Growth, Financial Literacy, Income Class, Income Mobility, Inequality

JEL Classification Code: D63, G53, I31, J6

\section{Introduction}

Poverty eradication is among the eight Millennium Development Goals (MDGs) of the United Nations Development Programme (UNDP). As a result, proportion of people living in extreme poverty decreased by more than half between 1990 and 2015. However, many are still struggling for basic needs such as food and shelter. Hence, this target was extended to No Poverty as part of Sustainable Development Goals (SDGs) which focused on most vulnerable, improving basic resources and services, and supporting communities affected by conflict and climaterelated disasters (UNDP). In the Philippines, this target was

${ }^{1}$ First Author and Corresponding Author. Assistant Professor, Department of Economics, College of Social Sciences and Development, Polytechnic University of the Philippines, Philippines [Postal Address: Anonas St., Mabini Campus, Sta. Mesa Manila, 1008, Philippines] Email: melcahmonsura@gmail.com

(c) Copyright: The Author(s)

This is an Open Access article distributed under the terms of the Creative Commons Attribution Non-Commercial License (https://creativecommons.org/licenses/by-nc/4.0/) which permits unrestricted non-commercial use, distribution, and reproduction in any medium, provided the unrestricted non-commercial use,
original work is properly cited. addressed by the government through 2011-2016 Philippine Development Plan (PDP) and expanded to PDP 2017-2022 (Ambisyon Natin 2040) which enables the government to systematically offer opportunities to find ways on how to get out of poverty, inequality, and poor state of human development (Monsura, 2020).

For instance, the country's poverty incidence among Filipino individuals in the first semester of 2015 declined by 6.6 percent $(6.6 \%)$ during the same period in 2018 , from 27.6 percent $(27.6 \%)$ to 21.0 percent $(21 \%)$ (Philippine Statistics Authority [PSA, 2020]). In addition, there is a 4.5 percent $(4.5 \%)$ decrease in subsistence incidence among Filipino individuals from 13.0 percent (13\%) in 2018 to 8.5 percent $(8.5 \%)$ in 2015 . These improvements in poverty status suggest that the government programs on poverty are helpful and beneficial.

Though government has done well in terms of eradicating poverty in recent times, the concept of income mobility as a measure of an individual's economic status needs to be addressed to analyze welfare. Compared to poverty analysis as a static approach, income mobility analysis uses longitudinal data to show the dynamic progress of an individual's well-being by examining income movement 
through time - upward movement and downward movement of income rank or class. Considering income mobility in the study is crucial because its concept involves inequality and economic security (Martinez et al., 2014). However, there is no comprehensive measure of economic mobility because of its dynamic process (Winfree, 2007) thus, this study measures income mobility using various mobility concepts and indices.

There are five ideas that can be used as aspects of income mobility - time dependence, positional movement, share movement, symmetric income movement, and directional income movement (Fields, 2000). These concepts were examined using indices such as ChiSquare value, Average Jump Index, Shorrocks' Mobility Index, and Fields-Ok decomposition approach. Fields-Ok decomposition approach determines the source of income mobility, whether there is income change because the (1) economy grew, and individual's income grew along with that or (2) people moved up and down within a given structure.

When there is economic growth, people tend to take economic opportunities such as entrepreneurship, savings, insurance, and investment. These opportunities were among the priorities of financial literacy which help the individuals become self-sufficient in terms of financial stability and contribute to upward movement of income mobility. Through financial literacy programs, economic inequalities will be reduced as well as information asymmetries between financial intermediaries and their stakeholders.

Hence, this paper aims to determine and measure the income mobility in the Philippines through estimating income mobility indices and identify the role of financial literacy on economic growth. In addition, the following three questions will be addressed: (1) when does one group of the households exhibit more income variation than another? (2) how will change in income inequality be affected when income mobility is present? (3) what are the sources of income mobility?

\section{Related Literature}

\subsection{Income Mobility Concepts and Measurements}

Income mobility means different things to different people depending on the use of its concepts and measurements (Fields, 2000; Fields, 2008; Jantti \& Jenkins, 2013). It is broadly defined as the shifting of socioeconomic units like individuals and households in the income hierarchy (Martinez et al., 2013). The concept of income mobility can be linked to economic growth when viewed in terms of how much incomes are changing. On the other hand, when viewed in terms of how much initial income status dictates future income trajectories, mobility can be linked to social justice. Furthermore, mobility can be linked to accessibility of socioeconomic opportunities when viewed in terms of its impact on the equality of income distribution. The different ideas of mobility were simplified by mobility analysts as how much income each recipient receives at two or more points in time (Fields, 2008). In this way, studies on income inequality and poverty, which are both static analysis, became different from those on income mobility because these allowed investigation of the movements of household's real income along the income ladder as well as those of demographic, structural and economic factors driving these changes (Aristei \& Perugini, 2015).

In general, the multidimensional feature of the income mobility concept can be contextualized in different ways. Mobility concepts may depend on individual's positional changes (Jantti \& Jenkins, 2013), share movement (individual experienced downward income mobility because the share of the total has fallen), symmetric income movement (people moving upward or downward within the income distribution), directional income movement, and time dependence. Decomposition of income fluctuations in this context analyzes the extent to which income mobility is due to economic growth and individual's income growing along with it, and the extent to which income mobility is due to people moving up and down within a given structure.

\subsection{Economic Growth and Financial Literacy}

During economic growth and as well as financial difficulties and challenges, financial problems can be avoided through financial literacy (Damayanti et al., 2018). Financial literacy as a human capital investment educates people on how to handle finances during economic crisis and on how to process economic information to make reasonable decisions on financial planning, wealth accumulations, borrowings, and pensions (Lusardi \& Mitchell, 2014). It also includes financial knowledge and awareness, financial skills and capability, and financial management which are key elements of stability and economic and financial growth in the economy (Potrich et al., 2015).

To increase financial literacy and improve financial knowledge and skills among individuals, inclusion of financial education in the school curriculum (Bangko Sentral ng Pilipinas [BSP], 2018) and incorporation of financial education and training into welfare programs (Zhan et al., 2006) are crucial. Individuals who graduated and availed these programs can have higher savings rate and higher net worth (Hogarth, 2006). This means that financial education has positive impact on the lives of individuals especially on income mobility. Specifically, financial education results in credit reduction, increase in savings, and assets acquisition (Hogarth, 2006). 


\section{Methodology}

\subsection{Data}

Most developing countries, including the Philippines, do not have genuine longitudinal panel data because the creation of this type of data have higher costs compared to cross sectional data with random respondents like Family Income and Expenditures Survey (FIES). Thus, this paper generated a pseudo-longitudinal panel data using the five-period survey of FIES from 2000 to 2015 (i.e. 2000-2003, 2003-2006, 2006-2009, 2009-2012, and 2012-2015). These years were considered since survey questionnaires of other years did not match with these years. Pseudo-longitudinal panel data can be an alternative approach in the absence of genuine longitudinal panels when independent repeated cross-sectional data is available (Russell \& Fraas, 2005). This means that the crosssectional data are comparable across subjects. FIES is a crosssectional data which provides data on income and expenditure differences of Filipino families. Hence, the utilization of the pseudo-longitudinal panel data is valid.

To track the households that were interviewed from the initial year (2000) to the final year (2015), a household data matching method was used. The data were filtered using various criteria such as household's location (region and province), household head's gender, and birthyear. The household head's age is expected to increase by three years for every survey after 2000. A household that was not qualified in this assumption was dropped in the sample. It is crucial to consider that measurement of income mobility can be done if the same households were interviewed from the start until the last year of the survey. The household expenditure which was treated as household income was converted into real value by deflation method using Consumer Price Index (CPI) with base year 2000.

Atotal of 21,163 households with their income classifications were included in the study after the process of data matching, as shown in Table 1. Most of the respondents belong to the Low-income Class of about 87.84 percent $(87.84 \%)$ wherein 62.71 percent $(62.71 \%)$ were poor in 2000 . The number of poor households decreased to 30.18 percent (30.18\%) in 2015 . On an average, Low-income Class declined by 5.75 percent (5.75percent). On the other hand, Middle-income Class has an average growth rate of 30.88 percent $(30.88 \%$ ), from 12.07 percent in 2000 to 35.32 percent $(35.32 \%)$ in 2015 . Although there are few households belonging to the upper-income Class, their number rose from 0.09 percent $(0.09 \%)$ to 0.29 percent $(0.29 \%)$ in the same period with an average growth of 78.75 percent. These indicate that for 15 years the households' income classes improved through time.

\subsection{Income Transition Matrix and Income Mobility Indices}

The households' income was divided into quintiles to derive quintile income matrices of the households from 2000 to 2015 which are presented in Table 2 below. This is useful to show and analyze the income classes of the households per period, from poorest (bottom quintile 1) to richest (top quintile 5). The rows show the income classes of time $t$ which is the initial year and the columns show the income classes of time $t+1$ which is the final year, each row and column sums to 100 percent $(100 \%)$. In addition, each cell shows the percentage of households who move from one quintile to another quintile from time $t$ to time $t+1$.

Table 1: Number of Respondents by Income Cluster

\begin{tabular}{|c|c|c|c|c|c|c|c|c|c|c|c|c|}
\hline \multirow{3}{*}{$\begin{array}{l}\text { Income Cluster } \\
\text { Poor }\end{array}$} & \multicolumn{12}{|c|}{ Year } \\
\hline & \multicolumn{2}{|c|}{2000} & \multicolumn{2}{|c|}{2003} & \multicolumn{2}{|c|}{2006} & \multicolumn{2}{|c|}{2009} & \multicolumn{2}{|c|}{2012} & \multicolumn{2}{|c|}{2015} \\
\hline & 13,271 & 62.71 & 14,576 & 68.87 & 10,220 & 48.29 & 9,955 & 47.04 & 6,710 & 31.71 & 6,388 & 30.18 \\
\hline $\begin{array}{l}\text { Low Income } \\
\text { (but not poor) }\end{array}$ & 5,318 & 25.13 & 4,388 & 20.73 & 6,410 & 30.29 & 6,653 & 31.44 & 7,228 & 34.15 & 7,239 & 34.21 \\
\hline $\begin{array}{l}\text { Lower Middle } \\
\text { Income }\end{array}$ & 2,095 & 9.90 & 1,737 & 8.21 & 3,373 & 15.94 & 3,423 & 16.17 & 4,859 & 22.96 & 4,977 & 23.52 \\
\hline Middle Income & 438 & 2.07 & 424 & 2.00 & 1,084 & 5.12 & 1,010 & 4.77 & 2,118 & 10.01 & 2,286 & 10.80 \\
\hline $\begin{array}{l}\text { Upper Middle } \\
\text { Income }\end{array}$ & 22 & 0.10 & 28 & 0.13 & 54 & 0.26 & 104 & 0.49 & 164 & 0.77 & 212 & 1.00 \\
\hline $\begin{array}{l}\text { Upper Income } \\
\text { (but not rich) }\end{array}$ & 10 & 0.05 & 5 & 0.02 & 15 & 0.07 & 14 & 0.07 & 55 & 0.26 & 38 & 0.18 \\
\hline Rich & 9 & 0.04 & 5 & 0.02 & 7 & 0.03 & 4 & 0.02 & 29 & 0.14 & 23 & 0.11 \\
\hline
\end{tabular}

Source of Raw Data: Family Income and Expenditure Survey

Notes: Income clusters were classified into three major groups such as Low-income Class (poor and low income but not poor), Middleincome Class (Lower Middle Income, Middle Income, and Upper Middle Income), and Upper-income Class (Upper Income but not rich and Rich) (Albert et al., 2015). 
Table 2: Income Transition Matrices: Households Income From 2000 to 2015

\begin{tabular}{|c|c|c|c|c|c|c|c|c|c|c|c|c|c|}
\hline & & \multicolumn{5}{|c|}{2003} & & & \multicolumn{5}{|c|}{2006} \\
\hline & & 1 & 2 & 3 & 4 & 5 & & & 1 & 2 & 3 & 4 & 5 \\
\hline \multirow{7}{*}{2000} & 1 & 0.31 & 0.26 & 0.19 & 0.14 & 0.1 & \multirow{5}{*}{2003} & 1 & 0.31 & 0.26 & 0.19 & 0.13 & 0.11 \\
\hline & 2 & 0.25 & 0.25 & 0.24 & 0.15 & 0.12 & & 2 & 0.24 & 0.26 & 0.22 & 0.16 & 0.12 \\
\hline & 3 & 0.19 & 0.2 & 0.21 & 0.21 & 0.19 & & 3 & 0.2 & 0.21 & 0.23 & 0.2 & 0.16 \\
\hline & 4 & 0.14 & 0.17 & 0.19 & 0.25 & 0.26 & & 4 & 0.15 & 0.15 & 0.19 & 0.24 & 0.27 \\
\hline & 5 & 0.11 & 0.13 & 0.17 & 0.25 & 0.34 & & 5 & 0.11 & 0.11 & 0.17 & 0.27 & 0.34 \\
\hline & & \multicolumn{5}{|c|}{2009} & & & \multicolumn{5}{|c|}{2012} \\
\hline & & 1 & 2 & 3 & 4 & 5 & & & 1 & 2 & 3 & 4 & 5 \\
\hline \multirow{7}{*}{2006} & 1 & 0.31 & 0.24 & 0.19 & 0.15 & 0.11 & \multirow{5}{*}{2009} & 1 & 0.29 & 0.24 & 0.21 & 0.14 & 0.12 \\
\hline & 2 & 0.24 & 0.27 & 0.22 & 0.16 & 0.12 & & 2 & 0.23 & 0.26 & 0.22 & 0.17 & 0.12 \\
\hline & 3 & 0.19 & 0.21 & 0.23 & 0.19 & 0.18 & & 3 & 0.2 & 0.22 & 0.22 & 0.21 & 0.16 \\
\hline & 4 & 0.14 & 0.16 & 0.19 & 0.24 & 0.27 & & 4 & 0.16 & 0.17 & 0.18 & 0.24 & 0.26 \\
\hline & 5 & 0.11 & 0.12 & 0.18 & 0.26 & 0.33 & & 5 & 0.12 & 0.11 & 0.17 & 0.25 & 0.35 \\
\hline & & \multicolumn{5}{|c|}{2015} & & & \multicolumn{5}{|c|}{2015} \\
\hline & & 1 & 2 & 3 & 4 & 5 & & & 1 & 2 & 3 & 4 & 5 \\
\hline \multirow{5}{*}{2012} & 1 & 0.3 & 0.24 & 0.19 & 0.15 & 0.12 & \multirow{5}{*}{2000} & 1 & 0.3 & 0.25 & 0.2 & 0.15 & 0.1 \\
\hline & 2 & 0.22 & 0.27 & 0.23 & 0.16 & 0.12 & & 2 & 0.22 & 0.27 & 0.22 & 0.17 & 0.12 \\
\hline & 3 & 0.21 & 0.2 & 0.21 & 0.2 & 0.17 & & 3 & 0.2 & 0.2 & 0.2 & 0.21 & 0.19 \\
\hline & 4 & 0.14 & 0.16 & 0.2 & 0.23 & 0.26 & & 4 & 0.15 & 0.16 & 0.19 & 0.24 & 0.26 \\
\hline & 5 & 0.13 & 0.12 & 0.17 & 0.25 & 0.33 & & 5 & 0.13 & 0.13 & 0.18 & 0.24 & 0.32 \\
\hline
\end{tabular}

The income matrix of 2000 to 2003 is almost the same with the other income matrices with an average change of one to two percent ( $1 \%$ to $2 \%$ ) in each quintile. On the average, from 2000 to 2015,30 percent $(30 \%)$ of the poorest stayed in the bottom quintile, 25 percent $(25 \%)$ moved to second quintile, and 10 percent (10\%) jumped into richest group. On the other hand, 32 percent $(32 \%)$ who belonged to richest quintile remained in the same group, while 13 percent (13\%) fell into poorest group. Although there are households who experienced income mobility, a greater number of households remained in their income class (as shown in diagonal entries).

The diagonal entries in the income matrices showed the income immobility of the households. To consider the income mobility comparisons across periods, mobility degree when household's income rank (in quintiles) moves in income distribution, average jump index (Jin-qi et al., 2009) was computed. It is defined as:

$$
\text { Average Jump Index }=1 / n \sum_{i=1}^{n}\left|P_{i}^{y}-P_{i}^{x}\right|
$$

where $P_{i}^{x}$ and $P_{i}^{y}$ denoted as the household's ordinal position in the income distribution at time $t$ and time $t+1$, respectively.
In addition, chi-square was computed using the $5 \times 5$ interperiod quintile income transition matrix to show how distant the actual transition matrix is from the observed frequencies $\left(O B S_{i j}\right)$. A larger $X^{2}$ value is more time dependent that makes the income less mobile than the other. It is defined as $\left(E X P_{i j}\right.$ is the expected frequencies):

$$
X^{2}=\sum_{i j}\left(O B S_{i j}-E X P_{i j}\right)^{2} / E X P_{i j}
$$

The relationship of income mobility and income inequality was measured in Shorrock's Mobility Index. Income inequality may be partly reduced when income mobility is present. A high mobility index means more reduction in income inequality. This index is defined as:

$$
m=I(x+y) / I(x+y) / U_{x}+U_{y}
$$

where the rigidity of the income distribution is denoted as $m$ and $I$ (.) is a particular scale of inequality (Fields, 2000).

The structure of income mobility was examined through decomposition approach. Fields-Ok mobility indices capture the total absolute and relative income mobility which are 
decomposable into two parts: (1) income mobility due to economic growth and (2) income mobility due to transfer effect (holding the mean constant). These are calculated as:

$$
\begin{aligned}
& M_{a}(x, y)=\sum_{j=1}^{n}\left|x_{i}-y_{i}\right| / \sum_{i=1}^{n} x_{i} \\
& M_{r}(x, y)=\frac{1}{n} \sum_{j=1}^{n}\left|\log x_{i}-\log y_{i}\right|
\end{aligned}
$$

where $x_{i}$ and $y_{i}$ denoted as base income and final income, respectively, with $n$ households at time $t$. Equation (4) is the absolute percentage mobility index (percentage of the mean base year income), while equation (5) represents relative mobility index which measures the income movement that are sensitive to base year incomes (logs of both base year and final year were considered rather than the income alone). These indices were decomposed into two parts to examine the structure of income mobility (Fields, 2000).

Suppose $(x, y)=\sum_{j=1}^{n}\left|x_{i}-y_{i}\right|$ represents the total income mobility, then it was decomposed into two parts as:

$$
(x, y)=\sum_{j=1}^{n}\left|x_{i}-y_{i}\right|=G_{n}(x, y)+T_{n}(x, y)
$$

If $G_{n(x, y)}=\sum_{i=1}^{n} y_{i}-\sum_{i=1}^{n} x_{i}$ to consider growth effect and $T_{n}(x, y)=2\left[\sum_{i \in \operatorname{Ln}(x, y)}^{n}\left(x_{i}-y_{i}\right)\right]$. to consider transfer effect, then the decomposed absolute mobility index is (Jinqi et al., 2009):

$$
\begin{aligned}
M_{a}(x, y)= & \left(1 / \sum_{i=1}^{n} x_{i}\right)\left(\sum_{i=1}^{n}\left(y_{i}-x_{i}\right)\right. \\
& +\left(1 / \sum_{i=1}^{n} x_{i}\right) 2\left[\sum_{i \in L_{n(x, y)}}^{n}\left(x_{i}-y_{i}\right)\right]
\end{aligned}
$$

and the decomposed relative mobility index is:

$$
\begin{aligned}
M_{r}(x, y)= & 1 / n \sum_{j=1}^{n}\left(\log y_{i}-\log x_{i}\right) \\
& +2 / n \sum_{i \in L}^{n}\left(\log y_{i}-\log x_{i}\right)
\end{aligned}
$$

The 'fokmob' command in STATA was used to decompose the total income mobility into growth effect and transfer effect.

\section{Results and Discussion}

\subsection{Profile of Households' Income}

Table 3 shows that the data set used in this study is reliable because the standard deviations are also close to the mean, which means that households' income are close to the average. Furthermore, the household incomes for 15 years, from 2000 to 2015 , with an average income of $172,968.20$ pesos and an average growth rate of 16.43 percent $(16.43 \%)$. Real income of households is increasing over time with an average minimum income of 8,312.96 pesos and has an average growth rate of 40.72 percent $(40.72 \%)$. On the other hand, maximum income decreased by 3.64 percent $(3.64 \%)$ through time.

From 2000 to 2015, the households' minimum income rose by more than 146 percent (146\%), from 4,473 pesos to $11,004.62$ pesos, annually. However, maximum income declined by 37.13 percent $(37.13 \%)$, from more than six million pesos to almost four million pesos, annually. There is a 37.27 percent $(37.27 \%)$ decline in the difference of minimum income and maximum income from 6,185,027 pesos in 2000 to $3,880,444.38$ pesos in 2015 . This showed that the gap between minimum income and maximum income decreased over time. This is reflected in an improvement of income distribution, targeting for income equality in which the country's estimated Gini coefficient of income of families at 0.4439 in 2015 is lower than the 2000 ratio at 0.4822 . This decline indicated an enhancement in income distribution towards a more equal or less unequal income distribution for the past fifteen years (PSA, 2017).

Table 3: Household Income from 2000 to 2015

\begin{tabular}{|l|c|c|c|c|}
\hline Year & Mean & Std. Dev. & Min. & Max \\
\hline 2000 & $123,038.50$ & $141,393.10$ & $4,473.00$ & $6,189,500.00$ \\
\hline 2003 & $109,821.20$ & $126,844.30$ & $3,153.34$ & $3,330,056.00$ \\
\hline 2006 & $166,927.00$ & $173,348.00$ & $9,992.52$ & $4,519,198.00$ \\
\hline 2009 & $169,067.80$ & $171,664.20$ & $12,008.92$ & $3,234,699.00$ \\
\hline 2012 & $231,097.10$ & $236,661.10$ & $9,245.35$ & $3,178,278.00$ \\
\hline 2015 & $237,857.60$ & $240,095.30$ & $11,004.62$ & $3,891,449.00$ \\
\hline Average & $172,968.20$ & $181,667.67$ & $8,312.96$ & $4,057,196.67$ \\
\hline
\end{tabular}

Source of raw data: FIES of Philippine Statistics Authority 


\subsection{Measurement of Household Income Mobility}

Households' income mobility in the Philippines was measured using various indices such as Chi-square, Average Jump Index, Atkinson et al. Mobility Ratio, and Shorrocks' Mobility Index as shown in Table 4. The decreasing values of Chi-squares over time indicate that households' income movement is more mobile. The households can easily move from lower income rank to higher income rank which will result in perceptible income mobility.

The Average Jump Index from 2000 to 2015 is increasing over time. This indicates that there is an improving income status, the low-income rank households moved to a higher income rank on the same income distribution. Income transition matrices concluded the same result. The size of the household movement between different income levels improved within fifteen years which means that the strengthening income mobility trend was evident. Although the fraction of immobility decreased from 1.274 in 20002003 period to 1.266 in 2003-2006 period, the proportions of income movements increased dramatically from 2006-2009 period to 2012-2015 period.

The 0.357 Atkinson et al. Mobility Ratio in 2000-2003 period increased to 0.37 in 2009-2012 period, this shows a 1.3 percent increase in mobility. A 0.001 percent $(0.001 \%)$ increase in mobility was seen in 2012-2015 period. Although this index quantifies the extent of mobility, it varies with the number of quintiles and distance between initial period and final year (Asadullah, 2012). The mobility ratio becomes smaller as the time frame becomes longer.

The Shorrock's Mobility Index determines the changes (whether increase or decrease) of income inequality when income mobility is present. The 0.912 Shorrocks' Mobility Index in 2000-2003 period was declined to 0.904 and 0.905 in periods 2003-2006 and 2006-2012, respectively. It was highest at 0.913 in 2009-2012 period. However, this returned to its original value of 0.912 in 2012-2015 period which indicates no change in income inequality when investigating the 2000-2003 and 2012-2015 periods. Meanwhile, the
0.918 , on an average, means that income inequality reduced by 91.80 percent $(91.80 \%)$ when there is income mobility.

The income mobility indices revealed that there is a presence of income mobility in the Philippines from 2000 to 2015. In addition, the households' income status improved over time which can give more economic opportunities. Accordingly, income inequality was reduced since income mobility is present in the country.

\subsection{Income Mobility Structure: Decomposition Approach}

The previous discussions showed that income mobility improved income inequality. However, the performance of income mobility is inconsistent through time. To increase mobility through time, it is necessary to examine the sources or factors that influence mobility. According to Fields and Ok (1996), income mobility may be due to growth effect, households gained from economic opportunities when there is economic growth, and transfer effect which means that there is income transfer from one household to another household but the total income in the economy remains the same. This can be done by Fields-Ok decomposition approach. The results were summarized in Table 5.

The findings revealed that income mobility was due to growth effect and transfer effect. Although there is an income mobility due to growth effect from 2000 to 2015 (absolute percentage index of 93.32 percent and 27.1 percent relative mobility index), there is a downward income movement due to economic shrinkage (negative growth) in 2000-2003 period. In 2003-2006 period, absolute income mobility due to growth effect rose to 103.81 percent $(103.81 \%)$ as economic growth rate increased by 3.1 percent $(3.1 \%$ ) (from 8.5 percent in 2000-2003 to 11.6 percent in 2003-2006). However, economic growth rate decreased to 8.7 percent $(8.7 \%)$ in 2006-2009 (decline of 2.9 percent) which resulted in lower income mobility due to growth effect (1.28 percent). On an average, there is 93.32 percent $(93.32 \%)$ growth effect in absolute.

Table 4: Household Income Mobility Measurement in the Philippines

\begin{tabular}{|l|c|c|c|c|}
\hline Time periods & $\begin{array}{c}\text { Chi-square } \\
\mathbf{X}^{\mathbf{2}}\end{array}$ & $\begin{array}{c}\text { Average Jump } \\
\text { Index, } \mathbf{M}_{\mathbf{p}}\end{array}$ & $\begin{array}{c}\text { Atkinson et al. } \\
\text { Mobility Ratio }\end{array}$ & $\begin{array}{c}\text { Shorrocks' Mobility } \\
\text { Index, } \mathbf{M}\end{array}$ \\
\hline $2000-2003$ & 0.46 & 1.274 & 0.357 & 0.912 \\
\hline $2003-2006$ & 0.491 & 1.266 & 0.353 & 0.904 \\
\hline $2006-2009$ & 0.4405 & 1.278 & 0.36 & 0.905 \\
\hline $2009-2012$ & 0.415 & 1.302 & 0.37 & 0.913 \\
\hline $2012-2015$ & 0.386 & 1.302 & 0.369 & 0.912 \\
\hline $2000-2015$ & 0.369 & 1.315 & 0.376 & 0.918 \\
\hline
\end{tabular}


Table 5: Income Mobility Decomposition and Economic Growth

\begin{tabular}{|l|c|c|c|c|c|}
\hline \multirow{2}{*}{ Time Period } & \multicolumn{2}{|c|}{ Fields-Ok Absolute Percentage Index } & Fields-Ok Relative Mobility Index & Economic \\
\cline { 2 - 5 } & Growth Effect & Transfer Effect & Growth Effect & Transfer Effect & Growth $^{\mathbf{2}}$ \\
\hline $2000-2003$ & $(10.74)$ & 61.18 & $(0.158)$ & 0.569 & 8.5 \\
\hline $2003-2006$ & 103.81 & 52.00 & 0.464 & 0.360 & 11.6 \\
\hline $2006-2009$ & 1.28 & 71.92 & 0.021 & 0.675 & 8.7 \\
\hline $2009-2012$ & 36.69 & 54.25 & 0.289 & 0.471 & 9.7 \\
\hline $2012-2015$ & 2.93 & 72.27 & 0.034 & 0.701 & 8.0 \\
\hline $2000-2015$ & 93.32 & 39.15 & 0.649 & 0.271 & 9.3 \\
\hline
\end{tabular}

Source: ${ }^{1}$ Author's estimation using STATA, ${ }^{2}$ Philippine Statistics Authority

Accordingly, absolute income mobility (individual's income when taken into isolation) and relative income mobility (analysis of an individual's income change with respect to the other individual's income change in his generation) due to growth effects are high when economic growth is also high. For instance, relative income mobility due to growth effect rose to 0.464 in 2003-2006 after the shrinkage effect in 2000-2003 period. This is reflected in the increase of economic growth from 8.5 percent $(8.5 \%)$ to 11.6 percent $(11.6 \%)$ in the same period. Since the economic growth declined in the following period, relative income mobility due to growth effect decreased as well. This behavior was observed for the rest of the period.

In contrast, income mobility due to transfer effects is high, for both absolute percentage index and relative mobility index, when economic growth is low - inverse relationship. With 8.5 percent $(8.5 \%)$ economic growth in 2000-2003, transfer effect for absolute and relative income mobility are 61.18 percent $(61.18 \%)$ and 0.569 , respectively. As economic growth rose by 3.1 percent $(3.1 \%)$ in 2003 2006, income mobility due to transfer effect declined. On the other hand, income mobility due to transfer effect increased as economic growth decreased by 2.9 percent $(2.9 \%)$, for both absolute and relative income mobility. This transfer of income from one household to another which resulted in income mobility of the households may be due to their participation in the lottery games (Banasihan et al., 2011; Matejowsky, 2003), wealth inheritance from parents to children, and debts (Estudillo et al. 2001). Households depend on this factor when there is lack of economic opportunities to earn more.

For 15 years, the growth effect is the leading factor of income mobility, income mobility is mainly influenced by income growth in the long term. Individuals take economic opportunities from economic growth to earn more and realize income mobility. However, financial management is needed to translate economic information and opportunities to growth. Financial sector development and access to finance with growth opportunities can help in the improvement of income distribution and promotes growth (Demirguc-Kunt \& Levine, 2008; Camba \& Camba, 2019) especially in the long-run period (Kumar \& Paramanik, 2020).

Thus, it can be noted that Filipino households learned how to take advantage of the economic opportunities through savings, investment, insurance, and entrepreneurship during growth. This is the result of the government's financial literacy program wherein households have the ability to process economic information and opportunities and make rational and well-informed decisions about financial planning (Lusardi \& Mitchell, 2014). Although financial literacy remains low in the country (BSP, 2018), the continuous and intensive financial literacy programs and financial inclusion policy reforms of the government make the individuals open-minded, informed, and well-trained on managing financial matters during economic growth. As part of the country's financial inclusion policy, financial literacy educates the households on proper spending and earning from income (interests and dividends from investment) that could result in financial stability of the households through rational decision making, funds management, insurance, and entrepreneurship (Department of Finance [DOF], 2016). Hence, financial inclusion has positive a effect on economic growth as well as income inequality reduction (Ratnawati, 2020).

\section{Conclusions}

The income status of the households improved from 2000 to 2015, movement of low-income rank households to higher income rank households. In addition, the income mobility indices showed that income mobility, both absolute and relative income mobility, is present in the Philippines. This income movement became more mobile through time. As income mobility takes place, income inequality reduction in the country is evident. 
Moreover, income mobility decomposition showed that growth effect is the main factor of income mobility. This means that households know how to take economic opportunities during economic growth. However, when the economy is not good and the opportunities are not enough, households tend to rely on lottery prizes, rewards, and borrowed money - transfer effect.

Although the increase of income mobility due to growth effect depends on growth, the small percentage of transfer effect compared to growth effect during shrinkage indicates that most Filipino households can manage their finances when the economy is in good and bad shape. The efforts of the government to educate individuals about financial literacy through financial inclusion policy is becoming significant with time. This success leads to financial stability of the households especially in utilizing the opportunities of economic growth such as savings, investment, insurance, and entrepreneurship.

\section{References}

Albert, J. R., Gaspar, R. E. \& Raymundo, M. J. (2015). Why we should pay attention to the middle class. Policy Notes No. 2015-13. Philippine Institute for Development Studies. Retrieved June 2, 2020, from https://pdfs.semanticscholar. org/8582/26bb48b6f31c5d43388f1da670ff7369f2e0.pdf

Aristei, D., \& Perugini, C. (2015). The drivers of income mobility in Europe. Economic Systems, 39(2), 197-224. https://doi. org/10.1016/j.ecosys.2014.06.007

Asadullah, M. N. (2012). Intergenerational wealth mobility in rural Bangladesh. Journal of Development Studies, 48(9), 1193-1208. https://doi.org/10.1080/00220388.2011.646988

Bangko Sentral ng Pilipinas. (2018). Bangko Sental ng Pilipinas to Conduct First Financial Education Stakeholders Expo. Retrieved March 27, 2020, from http://www.bsp.gov.ph/ publications $/$ media.. sp $? \mathrm{id}=4868 \& \mathrm{yr}=2018$

Banasihan, K. R., Dela Cruz, C. C., \& Ong, J. A. (2011). The level of satisfaction in life of the regular lotto players in Baybayin, Los Baños, Laguna. Ani: Letran Calamba Research Report, 1(1). https://ejournals.ph/article.php?id=132

Camba, A. C., \& Camba, A. L. (2019). The dynamic relationship of domestic credit and stock market liquidity on the economic growth of the Philippines. Journal of Asian Finance, Economics and Business, 7(1), 37-46. https://doi.org/10.13106/jafeb.2020. vol7.no1.37

Damayanti, S. M., Murtaqi, I., \& Pradana, H. A. (2018). The importance of financial literacy in global economic era. The Business and Management Review, 9(3), 435-441. https:// cberuk.com/cdn/conference_proceedings/2019-07-14-11-0317-AM.pdf

Demirguc-Kunt, A. \& Levine, R. (2007). Finance and economic opportunity. Proceedings of the Annual Bank Conference on Development Economics. Bled, Slovenia. Retrieved August
20, 2020, from http://documents1.worldbank.org/curated/ en/789171468349832745/pdf/wps4468.pdf

Department of Finance. (2016). The Philippines' financial literacy program. Presentation made by Undersecretary Gil Beltran at the 10th Financial Literacy Summit on 20 April 2016. Retrieved March 27, 2020, from https://www.dof.gov.ph/the-philippinesfinancial-literacy-program/

Estudillo, J. P., Quisumbing, A. R., \& Otsuka, K. (2001). Gender differences in wealth transfer and expenditure allocation: Evidence from rural Philippines. The Developing Economies, 39(4), 366-394. https://doi.org/10.1111/j.1746-1049.2001. tb00903.x

Fields, G. (2000). Income mobility: Concepts and measures: Patterns and underlying Causes." Cornell University ILR School. https://doi.org/10.1057/9780230625594_6

Fields, G. (2008). Income mobility. Cornell University, ILR School. Retrieved October 10, 2019, from http://digitalcommons.ilr. cornell.edu/articles/453/

Fields, G., \& Ok, E.A. (1996). The meaning and measurement of income mobility. Journal of Economic Theory, 71(2), 349-377. https://doi.org/10.1006/jeth.1996.0125

Hogarth, J. M. (2006). Financial education and economic development. Retrieved July 10, 2020, from https://www.oecd. org/finance/financial-education/37742200.pdf

Jantti, M., \& Jenkins, S. (2013). Income mobility. Institute for the Study of Labor Discussion Paper No. 7730. Retrieved August 17, 2020, from http://ftp.iza.org/dp7730.pdf

Jin-qi, J., Qiang, L., \& Guang-sheng, Z. (2009). The income mobility in rural China: Measurement and decomposition. http://dx.doi.org/10.2139/ssrn.1645842

Kumar, K., \& Paramanik, R. N. (2020). Nexus between Indian economic growth and financial development: A non-linear ARDL approach. Journal of Asian Finance, Economics and Business, 7(6), 109-116. https://doi.org/10.13106/jafeb.2020. vol7.no6.109

Lusardi, A., \& Mitchell, O. (2014). The economic importance of financial literacy: Theory and evidence. Journal of Economic Literature, 52(1), 5-44. DOI: 10.1257/jel.52.1.5

Martinez, A. Jr., Western, M., Haynes, M., \& Tomaszewski, W. (2013). Measuring income mobility using pseudo-panel data. The Philippine Statistician, 62(2), 71-99. https://www.psai.ph/ docs/publications/tps/tps_2013_62_2_5.pdf

Martinez, A. Jr., Western, M., Haynes, M., \& Tomaszewski, W. (2014). Is there income mobility in the Philippines? Asian Pacific Economic Literature, 28(1), 96-115. https://doi. org/10.1111/apel.12047

Matejowsky, T. (2003). Spider wrestling and gambling culture in the rural Philippines. Philippine Studies: Historical and Ethnographic Viewpoints, 51(1), 147-163. https:/www.jstor. org/stable/42633640

Monsura, M. P. (2020). Philippine household income mobility measurement and its decomposition using a pseudo-longitudinal 
panel data. Journal of Reviews on Global Economics, 9, 249-256. https://doi.org/10.6000/1929-7092.2020.09.24

Philippine Statistics Authority. (2017). 2015 Full Year Poverty Statistics. Retrieved February 20, 2020, from https://psa.gov. $\mathrm{ph} /$ content/poverty-incidence-among-filipinos-registered-2162015-psa

Philippine Statistics Authority. (2020). 2018 First Semester Poverty Statistics. Retrieved February 20, 2020, from https://psa.gov. $\mathrm{ph} /$ content/proportion-poor-filipinos-registered-210-percentfirst-semester-2018

Potrich, A. C., Vieira, K. M., \& Kirch G. (2015). Determinants of Financial Literacy: Analysis of the Influence of Socioeconomic and Demographic Variables. Accounting and Finance Review, 26(69), 362-377. https://www.scielo.br/pdf/rcf/v26n69/ en_1808-057x-rcf-26-69-00362.pdf

Ratnawati, K. (2020). The impact of financial inclusion on economic growth, poverty, income inequality, and financial stability in Asia. Journal of Asian Finance, Economics and Business, 7(10), 73-85. https://doi.org/10.13106/jafeb.2020. vol7.no10.073

Russell, J. E., \& Fraas. J. W. (2005). An application of panel regression to pseudo panel data. Multiple Linear Regression Viewpoints, 31(1). 1-15. http://citeseerx.ist.psu.edu/viewdoc/ download?doi=10.1.1.583.2683\&rep=rep1\&type $=$ pdf

Winfree, P. (2007). Analyzing economic mobility: Measuring inequality and economic mobility. Webmemo No. 1478, The Heritage Foundation. Asian Development Bank. (2019). Retrieved March 27, 2020 from https://www.adb.org/countries/ philippines/economy

Zhan, M., Anderson, S. G., \& Scott, J. (2006). Financial knowledge of the low-income population: Effects of a financial education program. The Journal of Sociology and Social Welfare, 33(1:4), 53-74. https://scholarworks.wmich. edu/jssw/vol33/iss $1 / 4$ 